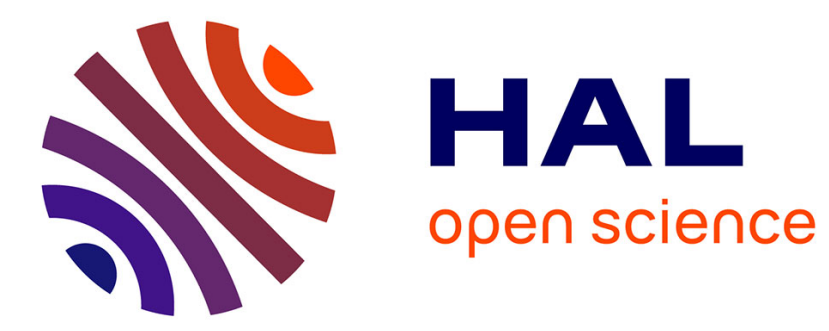

\title{
Association between Aphis gossypii genotype and phenotype on melon accessions
}

Sophie Thomas, Catherine Dogimont, Nathalie Boissot

\section{To cite this version:}

Sophie Thomas, Catherine Dogimont, Nathalie Boissot. Association between Aphis gossypii genotype and phenotype on melon accessions. Arthropod-Plant Interactions, 2012, 6 (1), pp.93-101. 10.1007/s11829-011-9155-2 . hal-02650233

\section{HAL Id: hal-02650233 \\ https://hal.inrae.fr/hal-02650233}

Submitted on 29 May 2020

HAL is a multi-disciplinary open access archive for the deposit and dissemination of scientific research documents, whether they are published or not. The documents may come from teaching and research institutions in France or abroad, or from public or private research centers.
L'archive ouverte pluridisciplinaire HAL, est destinée au dépôt et à la diffusion de documents scientifiques de niveau recherche, publiés ou non, émanant des établissements d'enseignement et de recherche français ou étrangers, des laboratoires publics ou privés.

\section{다)(1) $(5$}

Distributed under a Creative Commons Attribution - NonCommercial| 4.0 International 


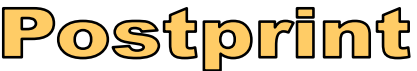

Version définitive du manuscrit publié dans / Final version of the manuscript published in : Arthropod-

Plant Interactions, 2011, DOI 10.1007/s11829-011-9155-2

\section{ASSOCIATION BETWEEN APHIS GOSSYPII GENOTYPE AND PHENOTYPE ON MELON ACCESSIONS}

Sophie Thomas, Catherine Dogimont and Nathalie Boissot

INRA, UR1052, Génétique et Amélioration des Fruits et Légumes, B.P. 94, F-84143 Montfavet cedex, France

Correspondance: Nathalie Boissot, Phone: +33 4327227 10, Fax: +33 4327227 02, E-mail:

Nathalie.Boissot@avignon.inra.fr

\section{ABSTRACT}

Development of molecular markers has allowed the characterization of several host-aphid interactions. We investigated the usefulness of microsatellite markers to characterize the plant- resistance interaction in the model Aphis gossypii/Cucumis melo. Six aphid clones, collected in different localities and years and belonging to two multilocus genotypes (MLGs) based on eight microsatellite markers were phenotyped on a set of 33 melon accessions, some of them known to carry the Vat gene. Three parameters were used: acceptance of plant, ability to colonize the plant and resistance to virus when inoculated by aphids. Concordance and correlation analyses showed that aphid clones sharing a same MLG exhibited a very agreeable phenotype on the set of accessions for acceptance of plant and resistance to virus when inoculated by aphids. From host point of view, melon accessions were grouped in four clear categories, resistant to aphids of both MLGs, only resistant to the NM1 MLG, only resistant to the C9 MLG, susceptible to both MLGs and another group of unclear characteristics. The four categories revealed different patterns of virulence for NM1 and C9 MLGs, that are likely controlled by a single avirulence gene in accordance with a gene for gene interaction. In contrast, the ability to colonize the plant appeared slightly variable among clones sharing a same MLG. We hypothesize it is due to the putative polygenic control of this aphid trait. Because the phenotypic variability of Aphis gossypii matched the genetic variability revealed by eight microsatellite markers, these markers could be used to infer the frequency of biotypes in field experiments and help to elucidate the allele diversity of melon resistance genes.

\section{KEYWORDS}

Plant resistance, Biotype, Vat gene, virus resistance, aphid resistance 


\section{INTRODUCTION}

In the past 15 years, DNA molecular markers have been developed to characterize the diversity of aphids. They have been widely used to resolve aphid species identity as well as to characterize the genotypes of individuals within populations, revealing patterns of genetic variation in relation with life cycle, ecology, demography, and climate (see Loxdale and Lushai (2007) for a review). Molecular markers allowed the characterization of host-plant associations in several aphid species (Frantz et al. 2006; Carletto et al. 2009) but very few studies have been reported that used molecular markers to investigate the interaction between plant resistance and aphids. The phenotypic variability of Acyrtosiphon pisum on resistant alfalfa cultivar was shown to match the genetic variability of A. pisum revealed by allozymes and RAPD markers (Bournoville et al. 2000). Although clones of Diuraphis noxia have overcome the Dn4-resistance in wheat, no genetic variability was revealed by seven SSR markers between avirulent and virulent populations (Shufran and Payton 2009). Fifty putative SNPs between two biotypes of Aphis glycine, virulent and avirulent on the Rap2 soybean resistance gene, were recently identified (Bai et al. 2010).

The cotton or melon aphid, Aphis gossypii Glover (Hemiptera: Aphididae), is a cosmopolitan species colonizing more than 600 host plants. It is a major pest of cucurbits and cotton (Blackman and Eastop 2007). Since the 1990s, molecular markers have been developed to characterize A. gossypii clones (Vanlerberghe-Masutti et al. 1999). They have allowed the description of a host race organization of the species (Carletto et al. 2009). Two hundred and eighty MLGs have been identified among individuals sampled on cucurbit crops; very few of them have been observed frequently and developed colonies (Thomas 2011). Among the clones adapted to cucurbit crops, 11 MLGs are closely related whereas one of them (named NM1) is distantly related to the other ones. Colonization of cucurbits by A. gossypii causes stunting and severe leaf curling that can result in plant death. Aphids also excrete honeydew on leaves and fruits, which serves as a growth medium for sooty mould. Moreover, they are efficient virus vectors and thus contribute to spread viral diseases. A. gossypii resistant melon accessions have been described since the 1970s, and a major gene, the Vat gene, and several QTLs controlling aphid resistance have been localized on the melon genome (Périn et al. 2002; Dogimont et al. 2004; Boissot et al. 2010). The Vat gene has the unique feature of conferring resistance to non-persistent viruses when vectored by A. gossypii (Lecoq et al. 1979; Lecoq et al. 1980). As early as 1971, Kishaba et al. reported the existence of biotypes of A. gossypii in US: they pointed out that melon resistance to the south-eastern biotype of aphids was inefficient against aphids of the south-western biotype. In the same manner, MacCarter and Habeck (1974) observed that melon resistance to the US south-western biotype of aphids was inefficient against aphids of the southeastern biotype. In Europe, Soria et al. (2000) observed a low resistance level to A. gossypii clones from Spain in melon accessions that exhibited a high level of resistance to French A. gossypii clones. In this context, the use of diverse aphid genotypes could be a new tool to better characterize the spectrum of efficiency of plant resistance genes. A major prerequisite is to know whether aphids sharing a same genotype (MLG) exhibit a same phenotype towards plant resistance. 
In this study, we investigated the relationship between genotype and phenotype in A. gossypii species using six clones characterized by microsatellite markers on one hand and by biological tests on 33 melon accessions on the other hand. The six clones were selected into two MLGs observed on cucurbit crops: the MLG C9 is found worldwide and groups with 11 other MLGs, whereas the MLG NM1 is restricted to France, it is genetically very distant of the C9 MLG. The set of melon accessions was built to represent $\mathrm{i} /$ the diversity of resistance sources known so far, ii/ a wide diversity of geographical origins (Asia, Africa, America and Europe) and iii/ the botanical groups (Pitrat et al. 2000). The phenotypic variability of the six clones was described using three parameters: acceptance of the plant, ability to colonize the plant and resistance to virus when inoculated by aphids.

\section{MATERIAL AND METHODS}

\section{Aphid clones and rearing}

Synchronous mass rearings of six A. gossypii clones collected on cucurbits were conducted on melon Védrantais at $24: 18^{\circ} \mathrm{C}$ under a $16 \mathrm{~h}$ : 8h photoperiod. NM1-lab and 4-106 were collected in south-eastern France in 1978 and 2004, respectively; A8 was collected in western France in 2008. NM1-lab and 4-106 were genotyped using 15 microsatellite markers (Lombaert et al. 2009) and A8 was genotyped using 8 microsatellite markers. These three clones share a same MLG, NM1. C9-lab, 3-99 and 4-104 were collected in south-eastern France in 1988, 2003 and 2004, respectively. They were genotyped using 15 microsatellite markers and they share a same MLG, C9 (Lombaert et al. 2009). Five-seven day-old aphids, apterous adults, were used for biological tests.

\section{Melon accessions}

Thirty-three accessions of Cucumis melo Linné were used to reveal A. gossypii variability. They belong to 12 out of the 17 botanical groups described in the melon species (Pitrat et al. 2000) and they originate from a wide diversity of geographical regions (Table 1). Some of them were chosen for their resistance to A. gossypii. The accession PI 161375, from which the Vat gene was cloned, was shown resistant to clones having either a NM1 or a C9 MLG (Boissot et al. 2010). It is also resistant to nonpersistent viruses when vectored by A. gossypii clone NM1-lab (Lecoq et al. 1980). Margot and Charentais Vat $\mathrm{R}$ are Charentais lines with aphid resistance originating from PI 161375. The aphid resistance in PI 414723 were shown to be controlled by the Vat locus (Klingler et al. 2001) and the aphid resistance and the virus resistance when inoculated by A. gossypii in PI 482420 were suggested to be controlled by the Vat locus (Sarria et al. 2008). Anso AL77 and 90625 were suggested to carry other alleles of resistance at the same Vat locus (Pitrat et al. 1988; Boissot et al. 2008; Dogimont et al. 2008).

\section{Biological characterization of A. gossypii clones}

Plantlets were grown in insect-proof greenhouse until they develop one or two leaves and then used in two types of biological tests. The first one allows characterizing the acceptance of the plant by A. gossypii and its ability to colonize the plant; the second one allows characterizing resistance to virus when inoculated by the A. gossypii aphid clones. 
To assess acceptance of the plant and ability to colonize the plant of $A$. gossypii clones, 10 apterous adults were deposited on a plantlet. The plantlets were then grown in a chamber at $24: 18^{\circ} \mathrm{C}$ under a 16h: 8h photoperiod. To prevent aphids leaving a plantlets from reaching another one, plantlets were isolated by putting each of them on a petri dish placed in a water-filled tray. Three days later, the number of aphids remaining on the plantlet was recorded as the 'Acceptance' parameter. Seven days after infestation, the adults were counted and the density of nymphs was estimated using a 0-6 scale (0 no nymph, 1 1 20 nymphs, 2 20 50 nymphs and 3 more than 50 nymphs observed on the infested leaf and on the rest of the plantlet; the two indices were added) . The 'Ability to Colonize' parameter at seven days was calculated as [density of nymphs + $\ln ($ number of adults +0.001$)$ ]; 'Ability to colonize' gives a balance weight to the number of adults (used for infestation and produced after seven days) and the number of nymphs (produced after seven days) observed on a plantlet seven days after infestation. 'Acceptance' and 'Ability to Colonize' parameters were collected on 33 accessions for the clones NM1-lab and 4-104 and on 10 to 25 accessions for the others clones (see Online Resource for details). The parameters were collected on 8-30 plantlets per accession.

To assess resistance to virus when inoculated by aphids, we first checked the CMV susceptibility of the accessions, we mechanically inoculated ten plants of each accession with the CMV isolate I17F. All accessions exhibited clear symptoms of CMV 15 days after mechanical inoculation. Then, to assess resistance to virus when inoculated by aphids, aphids from mass rearings were transferred to CMV (isolate I17F)-infected leaves of melon 'Védrantais' for 10 min virus acquisition. Batches of 10 aphids were deposited on plantlets for inoculation. After $15 \mathrm{~min}$, the aphids were removed, and plants were sprayed with aphicide, pyrimicarb (NM1 MLGs) or endosulfan (C9 MLGs), and placed into an insect proof glasshouse. The occurrence of infected plants was determined 20 days after inoculation by visual assessment of symptoms. 'Resistance to virus when inoculated by aphids' parameter was collected on 33 accessions for the clones NM1-lab and 4-104 and on 10 to 25 accessions for the others clones (see the Online Resource for details). Nine to 40 plantlets were tested per accession.

\section{$\underline{\text { Data analysis }}$}

Numerous tests were conducted from 2004 to 2010 what induced specific variations (season effect on plant growth, aphid fitness ...). To be able to compare all the tests, two lines, Védrantais (a Charentais line susceptible to aphids) and Margot (a Charentais line with aphid resistance introgressed from PI 161375), were inoculated in all tests (8 to 15 plantlets). Data obtained on both lines were used to define references.

The first step was to determine a score for 'Acceptance', (A), for each clone on Védrantais and Margot. For that, we pooled the data of 'Acceptance' obtained in all the tests on Védrantais and Margot and we analyzed the clone and melon line effects using a non parametric multiple comparisons proposed by Dunn and described by Siegel and Castellan (1998). According to the group identified by the statistical analysis, scores were given to each pair 'aphid clone $x$ Védrantais', $(A)_{V}$, and 'aphid clone $\mathrm{x}$ Margot', $(\mathrm{A})_{\mathrm{M}}$. The second step was to determine a $(\mathrm{A})$ score for each pair 'aphid clone $\mathrm{x}$ accession'. For that, for each clone, 'Acceptance' of each melon accession was compared to 'Acceptance' observed on Védrantais and Margot in the same test by non parametric multiple 
comparisons proposed by Dunn. From these analyses, for a given clone, each pair 'aphid clone $x$ accession' was scored either as $(A)_{V}$ or as $(A)_{M}$ or intermediate between $(A)_{V}$ and $(A)_{M}$. The third step was to identify the significantly associated clones for (A) using the Kendall's coefficient of concordance (W) (Kendall 1955). (W) is usually used for assessing agreement among raters; in this study, accessions are considered as raters of aphid clones. Kendall's W ranges from 0 (no agreement) to 1 (complete agreement). The strength of the relationship between pairs of clones was assessed by the coefficient of correlation of Kendall $(-1<\tau<1)$, that better takes into account ex-aequos than the coefficient of correlation of Spearman. The same procedure was applied to the parameter 'Ability to Colonize' and a score, (C), was given to each pair 'aphid clone $\mathrm{x}$ accession'.

We analyzed the clone and melon line (Margot and Védrantais) effects on resistance to CMV when aphid-transmitted from data obtained in all the tests using Monte Carlo exact test on $\chi^{2}$ statistics (comparison of the proportion of infected and symptomless plantlets). According to this statistical analysis, (V) scores were given to each pair 'aphid clone $\mathrm{x}$ Védrantais', $(\mathrm{V})_{\mathrm{V}}$, and 'aphid clone $\mathrm{x}$ Margot', $(\mathrm{V})_{\mathrm{M}}$. For each clone, 'Resistance to Virus when inoculated by aphids' of each melon accession was compared to 'Resistance to Virus when inoculated by aphids' of Védrantais and Margot observed in the same test by Monte Carlo exact test on $\chi^{2}$ statistics. Because there were two comparisons per accession, p was fixed at 0.025 for significant differences. From these analyses, each pair 'aphid clone $\mathrm{x}$ accession' was scored either as $(\mathrm{V})_{\mathrm{V}}$ or as $(\mathrm{V})_{\mathrm{M}}$ or intermediate between $(\mathrm{V})_{\mathrm{V}}$ and $(\mathrm{V})_{\mathrm{M}}$. The association between clones was assessed as described above for (A) and (C).

\section{RESULTS}

To compare six clones of $A$. gossypii we investigated three traits, the acceptance of the plant by A. gossypii and its ability to colonize the plant as well as resistance to virus when inoculated by $A$. gossypii aphids. These traits were measured on a set of melon accessions that were considered as raters of the aphid clones.

\section{Characterisation of six A. gossypii clones on the melon lines Védrantais and Margot}

Acceptance and ability to colonize plant: Twenty-one to 74 melon plants of Védrantais and Margot, which carries the Vat gene, were infested by aphids belonging to the clones 3-99, C9-lab, 4-106 and A8 and more than 150 plants of both lines were infested by aphids belonging to the clones NM1-lab and 4-104. All clones did significantly less accept Margot than Védrantais (Figure 1). Seven to nine aphids stayed on Védrantais plantlets 72 hours after infestation; two to seven aphids stayed on Margot plantlets. The 'Ability to Colonize' was calculated from the number of nymphs and adults on a plantlet seven days after infestation; it ranged from -0.3 to 7.8 (Figure 2). All clones did significantly less colonize Margot than Védrantais.

Resistance to virus when inoculated by aphids: CMV was inoculated to 30 to 50 melon plants of Védrantais and Margot using the clones 3-99, C9-lab, 4-106 and A8 as vectors and to more than 100 plants of both lines using the clones NM1-lab and 4-104 as vectors. The percentage of plants exhibiting CMV symptoms varied from 73 to $94 \%$ on Védrantais; the percentage of plants exhibiting 
CMV symptoms was less than $10 \%$ on Margot whatever the aphid clone (Figure 3). The results indicate that this trait may be considered as qualitative.

Scores assignation to each combination 'clone x reference melon line': To be able to compare the parameters for several clones on a large set of melon accessions, the parameters observed for each clone on both lines Védrantais and Margot, inoculated in each test, were used as references. A (A) score for 'Acceptance' and a (C) score for 'Ability to Colonize' was assigned to each combination 'clone x reference melon line' on the basis of non-parametric analyses (Figures 1 and 2). For (A) as well as for (C), the scores on Védrantais were from 1 to 4 and the scores on Margot from 5 to 6 . The $\chi^{2}$ tests conducted to compare the proportion of plants exhibiting CMV symptoms for each pairs of 'vectoring clone $\mathrm{x}$ reference melon line' revealed a highly significant effect of the melon line (Védrantais vs Margot) and no significant effect of the clone (Figure 3). Thus, the (V) score assigned to the combinations was 1 with Védrantais and was 5 with Margot, whatever the clone. For the three parameters (A), (C) and (V) the scores established for each combination 'clone $x$ reference melon line' were used as references to establish the scores of the three parameters (A), (C) and (V) for each combination 'clone $\mathrm{x}$ accession'.

\section{A. gossypii clones characterization on a set of 33 melon accessions}

Ten to 33 melon accessions were infested with the six clones of A. gossypii and were given (A), (C) and (V) scores (see Online Resource for details). The Kendall's coefficients of concordance (W) were used to identify groups of clones exhibiting the same pattern of phenotypes on a set of melon accessions. For (A), (C) and (V) scores, (W) was calculated including the six clones or including only the clones sharing a same MLG (Table 2). (W) of (A), (C) and (V) scores are weak $(<0.75)$ when considering the six clones. Therefore, when considering the six clones, the ranking of the accessions was not agreeable for (A), (C) and (V), i.e. the clones did not have a concordant pattern of phenotypes on the set of accessions for 'Acceptance', 'Ability to Colonize' and, 'Resistance to Virus when inoculated by aphids'. In contrast, (W) of (A) and (V) scores are remarkably high (over 0.95) when considering the clones sharing either a C9 MLG or a NM1 MLG and the mean $r$ of (A) and (V) are over 0.9. Therefore, when considering the clones having a same MLG, either C9 or NM1, the ranking of the accessions was agreeable for (A) and (V), i.e. the accessions the most accepted by a clone of a given MLG were also the accessions the most accepted by other clones sharing the same MLG; on the same way, accessions exhibiting virus symptoms after inoculation by a clone of a given MLG exhibited also virus symptoms after inoculation by the other clones sharing the same MLG. (W) of (C) is weak $(<0.75)$ when considering the clones sharing a C9 MLG. (W) of (C) is high $(0.92)$ when considering the clones sharing a NM1 MLG but the mean $r$ of (C) is under 0.9 for these clones. The clones did not have a highly concordant pattern of phenotypes for (C) on the set of accessions whatever the group of clones we considered.

Concordance analyses showed that aphid clones sharing a same MLG exhibited a very agreeable (A) and (V) on a set of melon accessions. We measured the strength of the relationship of pairs of clones for both traits using the Kendall's coefficient of correlation $\tau$. For 'Acceptance', $\tau$ are from 0.8 
to 0.9 between (A) obtained with the clones sharing a same MLG (Table 3). For 'Resistance to Virus when inoculated by aphids', $\tau$ are from 0.9 to 1 between $(\mathrm{V})$ obtained with the clones sharing a same MLG (Table 4). In contrast, for (A) and (V) $\tau$ were weak when considering clones not sharing a same MLG. Therefore, correlation analyses confirmed the conclusion of the concordance analyses. For both traits, 'Acceptance' and 'Resistance to Virus when inoculated by aphids', the pattern of clones having on one hand a C9 MLG and on the other hand a NM1 MLG can be illustrated by the phenotypes of the 4-104 and NM1-lab clones that were used to infest 33 melon lines. When considering 'Resistance to Virus when inoculated by aphids', a trait that may be considered as qualitative, the clone 4-104 exhibited $(\mathrm{V})=5$, on 12 out of the 33 melon lines, the clone NM1-lab exhibited $(\mathrm{V})=5$ on seven out of the 33 melon lines (see Online Resource for details). Finally, according to (V), accessions could be ordered into five classes. The first one comprised 17 accessions resistant to both clones, such as Margot; the second one comprised a single accession (Smiths' Perfect) which is only resistant to the 4104 clone; the third one comprised six accessions only resistant to the NM1-lab clone, such as 90625; the fourth one comprised seven accessions susceptible to both clones such as Védrantais. Two accessions were not clearly assigned to one of these four classes. (A) scores observed in the first class (resistant to both clones) varied from 1 to 4 except for Miel blanc and PI 164323 ((A) from 4 to 6). (A) scores observed for the clones sharing a C9 MLG appeared higher than (A) scores observed for the clones sharing a NM1 MLG. (A) scores observed in the third class (resistant to the clones having a NM1 MLG, susceptible to the clones having a C9 MLG) were 1 or 2 with the clones having a NM1 MLG and 3 to 6 with the clones having a C9 MLG.

In order to investigate the aggressiveness of clones within a MLG, we took into account (A) obtained on a sub-set of accessions infested by the three clones sharing a same MLG (Figure 4). Among the three clones sharing a C9 MLG, the C9-lab clone exhibited a significantly higher aggressiveness than the 3-99 clone, while the 4-104 clone showed an intermediate aggressiveness between the C9-lab and 3-99 clones. Among the three clones sharing a NM1 MLG, the 4-106 clone exhibited a significantly higher aggressiveness than the A8 and NM1-lab clones.

\section{DISCUSSION}

To investigate the aphid phenotypic diversity between MLGs and within a same MLG, our strategy was to offer a large variability of hosts (33 melon accessions, some known for their resistance to A. gossypii) to several clones having two genetically distant MLGs, the MLG C9 found worldwide and, the MLG NM1 restricted to France. These two MLGs have been regularly sampled on cucurbit crops in France. For each MLG, we used clones collected on a large scale of time (from 1988 to 2008) and in different growing areas in Southern France. Melon accessions were considered as raters of the aphid clones.

Concordance and correlation analyses showed that clones collected in different localities and different years, but sharing a same MLG, had a same pattern of responses on a large set of melon accessions for their 'Acceptance' and 'Resistance to Virus when inoculated by aphids'. On the same 
way, aphid resistance pattern observed on several melon accessions infested with clones from Sudan and France, sharing a C9 MLG, were consistent (Boissot et al. 2008) and as well as virus resistance pattern (unpublished data). Clones with distinct MLGs did not exhibit a concordant pattern of response for (A) and (V). Therefore, the eight microsatellite markers used to designed MLGs, appeared enough to differentiate two groups of A. gossypii facing melon accessions. These two groups can be considered as biotypes. This result could be puzzling, but has to be considered in accordance with the genetic structure of A. gossypii species. Lineages observed on cucurbits in southern France have a parthenogenetic reproduction (Thomas 2011) and therefore no gene flow may occur between lineages.

Several accessions from the set (Margot, Charentais Vat R, PI 161375, Anso AL77, 90625, PI 414723 and PI 482420) studied here are known to carry the Vat allele or another allele at the same locus. Based on the widely assumed knowledge on the NBS-LRR proteins, Dogimont et al. (2010) speculated that the Vat-mediated resistance results from the recognition (direct or indirect) between the product of the Vat gene and that of an avirulence gene of A. gossypii, which activates a cascade of plant responses, leading on one hand to the inhibition of plant virus infection and on the other hand to non acceptance of plants by the aphids and to a low ability to colonize the plant. In our study, acceptance and resistance to viruses when inoculated by aphids appeared dependent on the aphid MLG, in accordance with the gene-for-gene relationship between aphid and melon genotypes predicted by the molecular feature of the Vat gene.

For 'Ability to Colonize', we only observed concordance of phenotypes for the clones sharing a NM1 MLG. This trait, that is a result of acceptance, daily fecundity, time for pre-adult development and, mortality of clones, exhibited a slight variability among the clones sharing a C9 MLG. Consistently, a variable phenotype for daily fecundity was reported for 24 clones sharing a C9 MLG and sampled in south-eastern France (Lombaert et al. 2009). To explain the variation among clones sharing a same phenotype, we favour the hypothesis that the ability to colonize plant, resulting from several life traits (including acceptance), is likely controlled by several aphid genes. If true, a few of these genes may have different allelic forms, due to mutations, in a same MLG defined by eight to 15 microsatellite markers and this genetic variability could lead to a slight variability in 'Ability to Colonize'. Aphids harbour several secondary symbiotic bacteria and there is growing evidence that they may modulate various important adaptive traits of their host such as host plant use (Frantz et al. 2009). However, secondary symbiotic bacteria are unlikely involved in phenotypic variability within a MLG in A. gossypii in southeastern France as individuals of A. gossypii sampled in this area were shown free of three secondary symbionts (Carletto et al. 2008). A third hypothesis concerns the epigenetic control of phenotypic plasticity. Phenotypic plasticity is defined as the development of different phenotypes from a single genotype depending of environment. Unfortunately, the mechanisms that underlie the development of alternative phenotypes are still largely unknown for many systems (see Aubin-Horth and Renn (2009) for review).

Biotypes are strains of insects with inherited differences in their ability to use a host species. They are convenient and useful designations for applied problems in agricultural pest management especially involving plant resistance. Typically in agriculture, whenever a resistant crop variety is no 
longer resistant, a new pest biotype is considered. Among aphid pests, this terminology has been largely used to describe relationship between plant resistance and pest. Most aphid resistances were shown biotype-specific, such as resistance to the greenbug, Shizaphis graminum, conferred by the $G b$ genes, to the European raspberry aphid, Amphorophora idaei, conferred by the $\mathrm{Ag}$ genes, to the soybean aphid, Aphis glycines, conferred by the Rag genes, and to the woolly apple aphid, conferred by the $\mathrm{Er}$ genes (Berzonsky et al. 2003; Sargent et al. 2007; Bus et al. 2008; Kim et al. 2008). The genotypic diversity of some of these aphid species has been recently studied but few relationships have been established between biotypes and genotypes. As previously observed for the interaction between A. pisum and alfalfa (Bournoville et al. 2000), we showed that biotype and genotype have a strong convergence in A. gossypii species in the frame of the interaction with the melon species. Therefore, the genotypic data, that can be obtained on a large number of individuals could be used to infer the frequency of biotypes in field experiments, and to study the effects of resistance gene deployment on the diversity of aphid populations.

In melon, the Vat gene confers resistance to the aphid A. gossypii and it has also the unique feature of conferring resistance to non-persistent viruses when inoculated by A. gossypii (Lecoq et al. 1979; Lecoq et al. 1980). We observed this double phenotype in accessions from all geographical origins and all botanical groups; nevertheless the double phenotype observed in the cantalupensis accessions from Europe is due to resistance introgression from the accession PI 161375. The accession PI 161375, from which the Vat gene was cloned, was shown resistant to four clones having either a NM1 or a C9 MLG (Boissot et al. 2008 ; Boissot et al. 2010). By enlarging the set of clones, the Vat allele from PI 161375 appeared to confer resistance to A. gossypii clones with a NM1 and C9 MLGs. By the same way, the allele at the Vat locus carried by the accession 90625 appeared to confer resistance only to A. gossypii clones with a NM1 MLG. In this study, we also showed that the accession Smiths' Perfect was only resistant to clones with a C9 MLG. In these three accessions, the acceptance and colonization by an aphid clone is associated with resistance to viruses when inoculated by this aphid clone. In this study, we identified several accessions, which did not exhibit this double phenotype. Thus, the accession PI 164323 exhibited resistance to virus when inoculated by aphids but was rather susceptible to aphids. This particular phenotype was observed on PI 164323 with both MLGs, it was also observed on Miel Blanc with aphids having a C9 MLG. On the contrary, Escrito exhibited susceptibility to virus when inoculated by aphids having a NM1 MLG but was rather susceptible to aphids having a NM1 MLG. Altogether, these results strongly suggest that other alleles at the Vat locus that those already known and/or new loci of resistance exist within the melon diversity.

\section{ACKNOWLEDGMENTS}

We thank Pascale Mistral, Virginie Chareyron and the staff of the experimental units of INRA in Avignon for technical assistance. Sophie Thomas received a phD fellowship funded by INRA and the Région Provence-Alpes-Côte d'Azur, France. 


\section{REFERENCES}

Aubin-Horth N, Renn SC (2009) Genomic relation norms: using integrative biology to understand molecular mechanisms of phenotypic plasticity. Mol Ecol 18: 3763-3780

Bai X, Zhang W, Orantes L, Jun T-H, Mittapalii O, Rouf Mian MA, Michel AP (2010) Combining next-generation sequencing strategies for rapid molecular resource development from an invasive aphid species, Aphis glycines. PlosOne 5: e11370

Berzonsky WA, Ding H, Haley SD, Harris M, Lamb RJ, Mc Kenzie R (2003) Breeding wheat for resistance to insects. Plant Breed Rev 22: 221-296

Blackman RL, Eastop VF (2007) Taxonomic Issues. In: van Emden HF, Harrigton R, eds. Aphids as crop pests. CABI, Oxfordshire, UK, pp 1-29

Boissot N, Mistral P, Chareyron V, Dogimont C (2008) A new view on aphid resistance in melon: The role of A. gossypii variability. In: Cucurbitaceae 2008, IXth EUCARPIA Meeting on Genetics and Breeding of Cucurbitaceae. Avignon, France, pp 163-171

Boissot N, Thomas S, Sauvion N, Marchal C, Pavis C, Dogimont C (2010) Mapping and validation of QTLs for resistance to aphids and whiteflies in melon. Theor Appl Genet 121: 117-125

Bournoville R, Simon JC, Badenhausser I, Girousse C, Guilloux T, Andre S (2000) Clones of pea aphid, Acyrtosiphon pisum (Hemiptera: Aphididae) distinguished using genetic markers differ in their damaging effect on a resistant alflafla cultivar. Bull Entomol Res 90: 33-39

Bus VGM, Chagne D, Basset HCM, Bowatte D, Calenge F, Celton JM, Durel CE, Malone MT, Patocchi A, Ranatunga AC, Rikkerink EHA, Tusti DS, Zhou J, Gardiner SE (2008) Genome mapping of three major resistance genes to woolly apple aphid (Eriosoma lanigerum Hausm.). Tree Genet Genomes 4: 223-236

Carletto J, Gueguen G, Fleury F, Vanlerberghe-Masutti F (2008) Screening the bacterial endosymbiotic community of sap-feeding insects by terminal-restriction fragment length polymorphism analysis. Entomol Exp Appl 129: 228-234

Carletto J, Lombaert E, Chavigny P, Brevault T, Lapchin L, Vanlerberghe-Masutti F (2009) Ecological specialization of the aphid Aphis gossypii Glover on cultivated host plants. Mol Ecol 18: $2198-2212$

Dogimont C, Bendahmane A, Chovelon V, Boissot N (2010) Aphid resistance in cultivated crops: genetic and molecular bases and interaction with aphid populations. C R Biologies 333: 566-576

Dogimont C, Bendahmane A, Pitrat M, Caboche M, Rousselle P, Pauquet J, Burget-Bigeard E, Hagen L, Chovelon V, Le Menn A (2004) Aphis gossypii resistance gene. France. World patent WO/2004/072109

Dogimont C, Chovelon V, Tual S, Boissot N, Rittener V, Giovinazzo N, Bendahmane A (2008) Molecular diversity at the Vat/Pm-W resistance locus in melon. In: Cucurbitaceae 2008, Proceedings of the IX ${ }^{\text {th }}$ EUCARPIA meeting on genetics and breeding of Cucurbitaceae. Avignon, France, pp 219-227

Frantz A, Plantegenest M, L. M, Simon J-C (2006) Ecological specialization correlates with genotypic differentiation in sympatric host-populations of the pea aphid. J Evol Biol 19: 392-401 93-101., DOI : 10.1007/s11829-011-9155-2 
Frantz A, Calcagno V, Mieuzet L, Plantegenest M, Simon JC (2009) Complex trait differentiation between host-populations of the pea aphid Acyrthosiphon pisum (Harris): implications for the evolution of ecological specialisation. Biological Journal of the Linnean Society 97: 718-727

Kendall M (1955) Rank Correlation Methods. Charles Griffin and Company, London, UK

Kim K-S, Hill CB, Hartman GL, Rouf Mian MA, Diers BW (2008) Discovery of soybean aphid biotypes. Crop Sci 48: 923-928

Kishaba AN, Bohn GW, Toba HH (1971) Resistance to Aphis gossypii in muskmelon. J Econ Entomol 64: 935-937

Klingler J, Kovalski I, Silberstein L, Thompson G, Perl-Treves R (2001) Mapping of cotton-melon aphid resistance in melon. J Amer Soc Hort Sci 126: 56-63

Lecoq H, Cohen S, Pitrat M, Labonne G (1979) Resistance to cucumber mosaic virus transmission by aphids in Cucumis melo. Phytopathology 69: 1223-1225

Lecoq H, Labonne G, Pitrat M (1980) Specificity of resistance to virus transmission by aphids in Cucumis melo. Ann Phytopathol 12: 139-144

Lombaert E, Carletto J, Piotte C, Fauvergue X, Lecoq H, Vanlerberghe-Masutti F, Lapchin L (2009) Response of the melon aphid, Aphis gossypii, to host-plant resistance: evidence for high adaptative potential despite low genetic variability. Entomol Exp Appl 133: 46-56

Loxdale HD, Lushai G (2007) Population genetic issues: The unfolding story using molecular markers. In: van Emden HF, Harrigton R, eds. Aphids as crop pests. CABI, Oxfordshire, UK, pp $31-67$

MacCarter LE, Habeck DH (1974) Melon aphid resistance in Cucumis spp. Fla Entomol 57: 195-204

Périn C, Hagen L, De Conto V, Katzir N, Danin-Poleg Y, Portnoy V, Baudracco-Arnas S, Chadoeuf J, Dogimont C, Pitrat M (2002) A reference map of Cucumis melo based on two recombinant inbred line populations. Theor Appl Genet 104: 1017-1034

Pitrat M, Maestro C, Ferrière C, Ricard M, Alvarez J (1988) Resistance to Aphis gossypii in Spanish melon (Cucumis melo). Cucurbit Genet Coop Rpt 11: 50-51

Pitrat M, Hanelt P, Hammer K (2000) Some comments on infraspecific classification of cultivars of melon. Acta Horticulturae 510:29-36

Sargent DJ, Fernandez-Fernandez F, Rys A, Knight VH, Simpson DW, Tobutt KR (2007) Mapping of A1 conferring resistance to the aphid Amphorophora idaei and $d w$ (dwarfing habit) in red raspberry (Rubus idaeus L.) using AFLP and microsatellite markers. BMC Plant Biol 7: 15

Sarria E, Yuste-Lisbona FJ, Palomares FJ, Lopez-Sesé AI, Gomez-Guillamon ML (2008) Inheritance of tolerance to Aphis gossypii in C. melo TGR-1151 and its relation with resistance to virus transmission. In: Cucurbitaceae 2008, IXth EUCARPIA Meeting on Genetics and Breeding of Cucurbitaceae. Avignon, France, pp 459-463

Shufran KA, Payton TL (2009) Limited genetic variation within and between Russian Wheat aphid (Hemiptera: Aphididae) biotypes in the united states. J Econ Entomol 102: 440-445

Siegel S, Castellan NJ (1998) Non parametric statistics for behavioral sciences. MacGraw-Hill, New York, USA 
Soria C, Diaz JA, Moriones E, Gomez-Guillamon ML (2000) Resistance to Aphis gossypii and to virus transmission by this aphid in melon. In: $7^{\text {th }}$ EUCARPIA Meeting on Cucurbit Genetics and Breeding. Ma'ale Ha Hamisha, Israel, pp 305-312

Thomas S (2011) Pressions de sélection exercées par les résistances génétiques du melon sur les populations d'Aphis gossypii. phD Thesis, Université d'Avignon et des pays de Vaucluse, France.

Vanlerberghe-Masutti F, Chavigny P, Fuller SJ (1999) Characterization of microsatellite loci in the aphid species Aphis gossypii Glover. Mol Ecol 8: 685-702 
Table 1. Geographical origins and botanical groups of 33 melon accessions used to characterize $A$. gossypii clones. In bold, the lines with aphid resistance known to be conferred by the Vat locus.

\begin{tabular}{|c|c|c|c|c|}
\hline Botanical groups & Asia & Africa & America & Europe \\
\hline Chinensis & $\begin{array}{l}\text { Chenggam } \\
\text { Miel Blanc } \\
\text { PI } 161375 \\
\text { PI } 255478 \\
\text { PI } 266935\end{array}$ & & & \\
\hline Conomon & Shiro Uri Okayama & & & \\
\hline Makuwa & $\begin{array}{l}\text { Ginsen Makuwa } \\
\text { K } 5442 \\
\text { Kanro Makuwa } 1 \\
\text { Kanro Makuwa } 2 \\
\text { Shiro Nashi Makuwa }\end{array}$ & & & \\
\hline Momordica & $\begin{array}{l}\text { MR-1 } \\
\text { PI } 414723\end{array}$ & & & \\
\hline Acidulus & 90625 & PI 482420 & & \\
\hline Ameri & PI 164323 & & & Persiski BR5 \\
\hline Agrestis & PI 164320 & & & \\
\hline & PI 164723 & & & \\
\hline Cantalupensis & & & & $\begin{array}{l}\text { Charentais Vat R } \\
\text { Charentais T } \\
\text { Margot } \\
\text { Védrantais }\end{array}$ \\
\hline Chito & & & Meloncillo & \\
\hline Flexuosus & & Fegouss 1 & & \\
\hline Reticulatus & & $\begin{array}{l}\text { PI } 224770 \\
\text { PI } 234607\end{array}$ & Smiths' Perfect & \\
\hline Inodorus & & & & $\begin{array}{l}\text { Anso AL } 77 \\
\text { Invernizo } 8427\end{array}$ \\
\hline unknown & Durgapura Madhu & PI 282448 & & Escrito 8429 \\
\hline
\end{tabular}


Table 2. Kendall's coefficients of concordance, W, of phenotypic traits of A. gossypii clones measured on n melon accessions (=raters). Three clones share a C9 MLG and three clones share a NM1 MLG. $\mathrm{r}$ $=$ mean coefficient of correlation.

\begin{tabular}{|c|c|c|c|c|}
\hline Traits & & All Clones & $\begin{array}{l}\text { Clones having a } \\
\text { C9 MLG }\end{array}$ & $\begin{array}{l}\text { Clones having a } \\
\text { NM1 MLG }\end{array}$ \\
\hline \multirow[t]{3}{*}{ Acceptance } & $\mathrm{W}$ & 0,74 & 0,95 & 0,95 \\
\hline & $\mathrm{r}$ & 0,68 & 0,93 & 0,92 \\
\hline & $\mathrm{n}$ & 8 & 14 & 15 \\
\hline \multirow[t]{3}{*}{ Ability to colonize } & W & 0,74 & 0,72 & 0,92 \\
\hline & $\mathrm{r}$ & 0,69 & 0,58 & 0,88 \\
\hline & $\mathrm{n}$ & 9 & 13 & 14 \\
\hline \multirow{4}{*}{$\begin{array}{l}\text { Resistance to virus } \\
\text { when } \\
\text { inoculated by aphids }\end{array}$} & & & & \\
\hline & W & 0,68 & 0,96 & 0,95 \\
\hline & $\mathrm{r}$ & 0,61 & 0,95 & 0,93 \\
\hline & $\mathrm{n}$ & 8 & 12 & 14 \\
\hline
\end{tabular}

Table 3. Coefficients of correlation between acceptance scores (A) after infestation of melon accessions by six clones of A. gossypii: 3-99, 4-104 and C9-lab (C9 MLG), 4-106, A8 and NM1-lab (NM1 MLG). Right part: Kendall coefficient (in bold when $\mathrm{p}<0.01$ ); left part: number of accessions observed for each pair of clones.

\begin{tabular}{lllllll}
\hline & $3-99$ & $4-104$ & C9-lab & $4-106$ & A8 & Nm1-lab \\
\hline 3-99 & & 0.9 & 0.9 & 0.7 & 0.6 & 0.7 \\
4-104 & 10 & & 0.8 & 0.5 & 0.2 & 0.3 \\
C9-lab & 10 & 19 & & 0.4 & 0.3 & 0.5 \\
4-106 & 10 & 19 & 13 & & 0.9 & 0.8 \\
A8 & 9 & 21 & 15 & 15 & & 0.9 \\
Nm1-lab & 10 & 33 & 19 & 19 & 21 & \\
\hline
\end{tabular}

Table 4. Coefficients of correlation between scores after CMV inoculation of melon accessions (V) by six clones of A. gossypii: C9-lab, 3-99 and 4-104 (C9 MLG), NM1-lab, 4-106 and A8 (NM1 MLG). Right part: Kendall coefficient (in bold when $\mathrm{p}<0.01$ ); left part: number of accessions observed for each pair of clones.

\begin{tabular}{lllllll}
\hline 1 & $3-99$ & $4-104$ & C9-lab & $4-106$ & A8 & NM1-lab \\
\hline 3-99 & & 0.9 & 0.9 & 0.7 & 0.5 & 0.7 \\
4-104 & 28 & & 0.9 & 0.5 & 0.6 & 0.5 \\
C9-lab & 12 & 15 & & 0.6 & 0.6 & 0.3 \\
4-106 & 23 & 25 & 9 & & 1.0 & 0.9 \\
A8 & 16 & 19 & 13 & 14 & & 0.9 \\
NM1-lab & 28 & 33 & 15 & 25 & 19 & \\
\hline
\end{tabular}




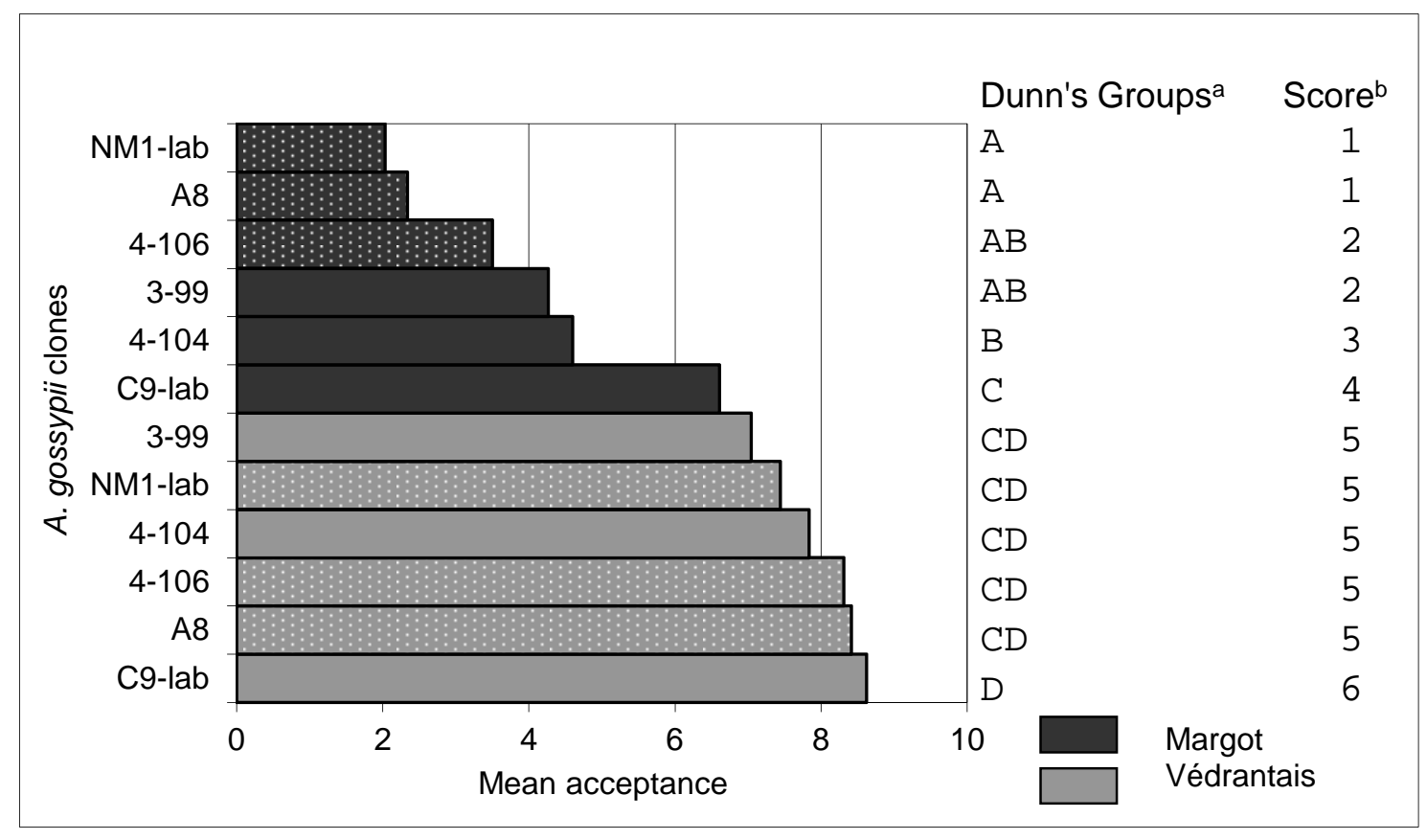

Fig. 1 Acceptance by six clones of A. gossypii of two melon lines, Védrantais (in grey) and Margot (in black). Acceptance $=$ number of aphids on the plant 72 hours after infestation by 10 aphids, spotted NM1 MLG, plain C9 MLG. ${ }^{a}$ significant difference $(p=0.05$, non parametric test (Dunn procedure) corrected for the Bonferroni effect), ${ }^{b}$ scores assigned to each clone on Védrantais and Margot.

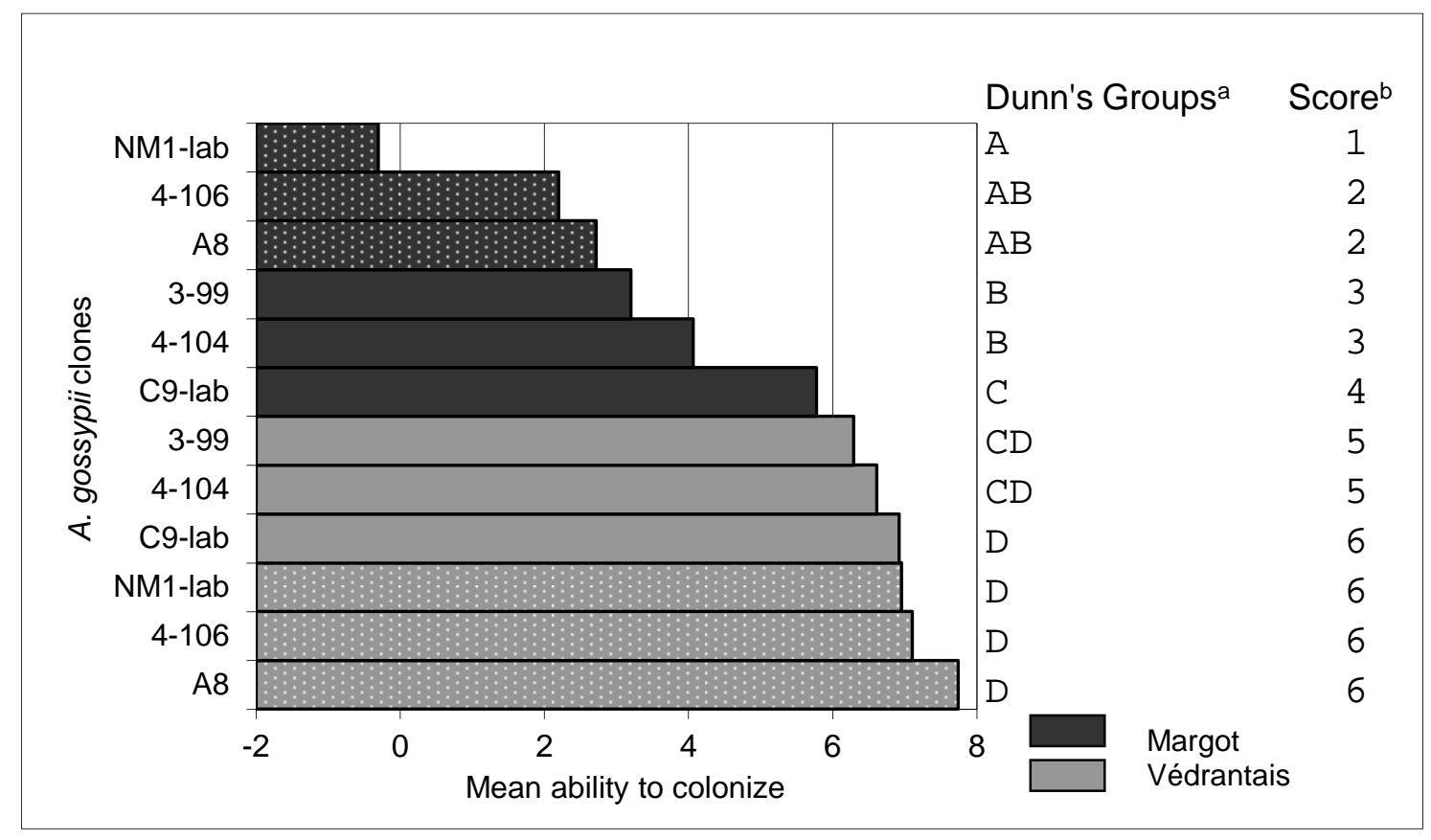

Fig. 2 Ability of six clones of A. gossypii to colonize two melon lines, Védrantais (in grey) and Margot (in black) observed seven days after infestation by 10 aphids, spotted NM1 MLG, plain C9 MLG ${ }^{\mathrm{a}}$ significant difference ( $\mathrm{p}=0.05$, non parametric test (Dunn procedure) corrected for the Bonferroni effect), ${ }^{\mathrm{b}}$ scores assigned to each clone on Védrantais and Margot. 


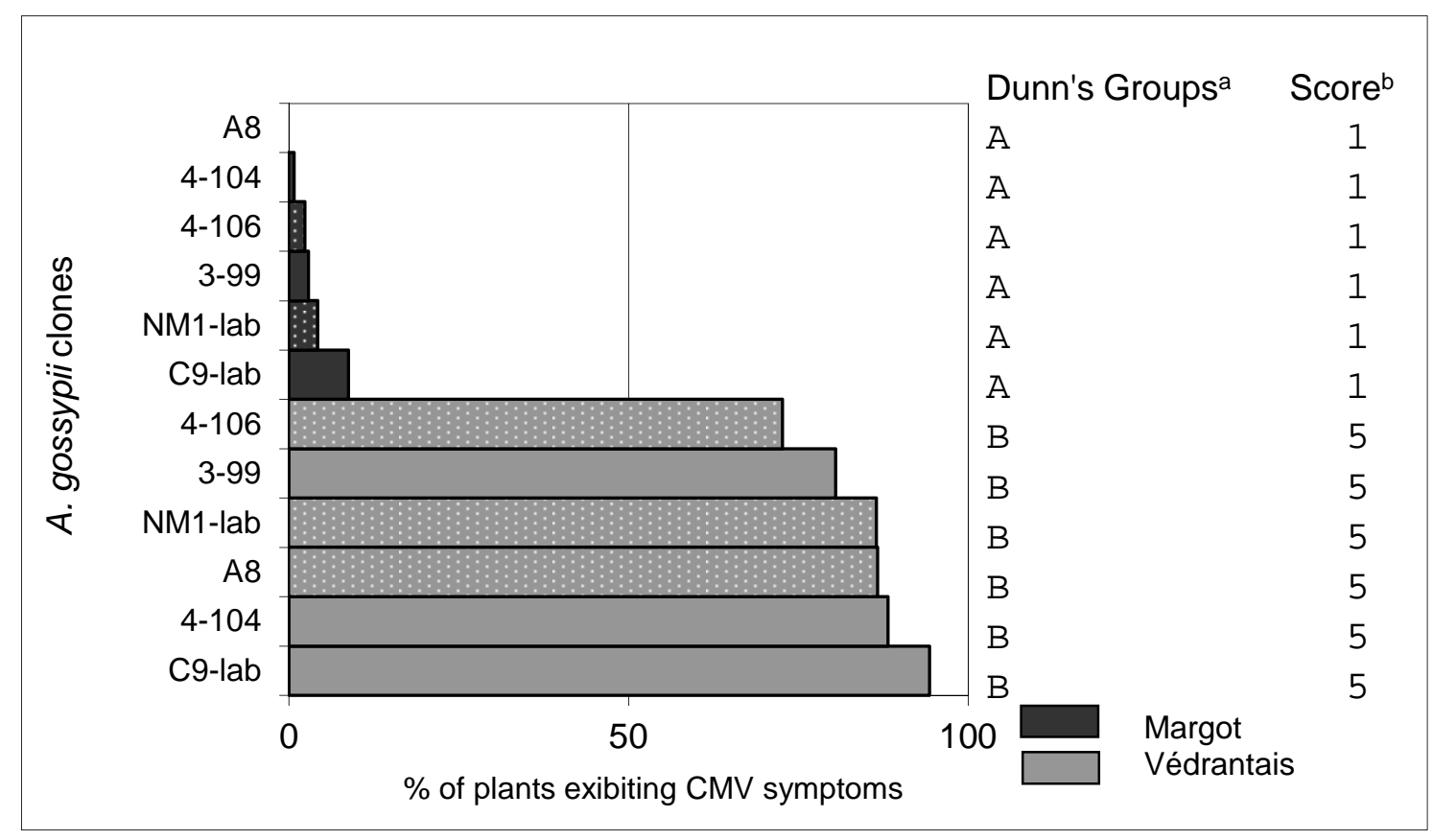

Fig. 3 Percentage of melon plants, Védrantais (in grey) and Margot (in black), with CMV symptoms after inoculation by six clones of $A$. gossypii aphids, spotted NM1 MLG, plain C9 MLG. ${ }^{\text {a }}$ significant difference $(\mathrm{p}=0.05)$ based pairwise comparison by $\chi^{2}$ statistics corrected for the Bonferroni effect $\left(\mathrm{p}_{\mathrm{cor}}=0.003\right),{ }^{\mathrm{b}}$ scores assigned to each clone on Védrantais and Margot.

a: clones with a C9 MLG

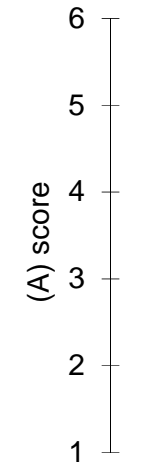

Dunn's group
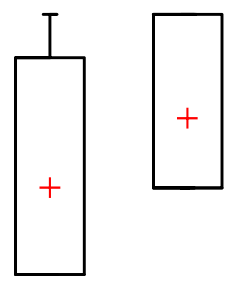

3-99 4-104 C9-lab

3-99 4-104 C9-lab

$A \quad A B \quad B$ b: clones with a NM1 MLG

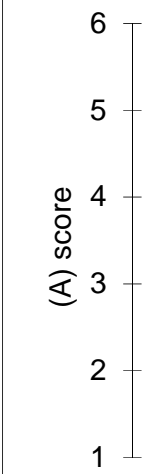

Dunn's group A
$4-106$

A8

NM1-lab
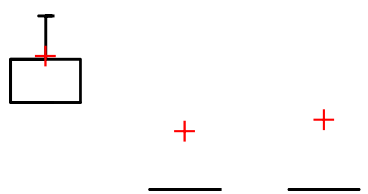

B

B

Fig. 4 Box plots (75\% of the data in the box) of acceptance (A) scores obtained for pairs 'melon accessions x A. gossypii clones' a: 10 melon accessions x 3 clones having a C9 MLG (3-99, 4-109 and C9-lab) and b: 15 melon accessions x 3 clones having a NM1 MLG (4-106, A8 and NM1-lab). Cross: Mean score; Dunn's group: significant difference $(\mathrm{p}=0.05$, non parametric test (Dunn procedure) corrected for the Bonferroni effect). 


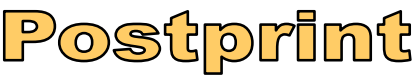

Version définitive du manuscrit publié dans / Final version of the manuscript published in : Arthropod-Plant Interactions, 2011, DOI 10.1007/s11829-011-9155-2

Online resource

$\mathrm{tT}$

A 'Acceptance' and C 'Ability to colonize' scores assigned to melon accessions when infested by 6 clones of A. gossypii and V (Resistance to virus when inoculated by aphids) scores assigned to melon accessions when CMV was inoculated by 6 clones of A. gossypii. A and C vary from 1 (accession resistant) to 6 (accession susceptible), $\mathrm{V}$ vary from 1 (accession resistant) to 5 (accession susceptible)

\begin{tabular}{|c|c|c|c|c|c|c|c|c|c|c|c|c|c|c|c|c|c|c|}
\hline \multirow{3}{*}{$\begin{array}{l}\text { MLG } \\
\text { Clones } \\
\end{array}$} & \multicolumn{9}{|c|}{ C9 } & \multicolumn{9}{|c|}{ NM1 } \\
\hline & \multicolumn{3}{|c|}{$3-99$} & \multicolumn{3}{|c|}{$4-104$} & \multicolumn{3}{|c|}{ C9-lab } & \multicolumn{3}{|c|}{ A8 } & \multicolumn{3}{|c|}{$4-106$} & \multicolumn{3}{|c|}{ NM1-lab } \\
\hline & $\mathrm{A}$ & $\mathrm{C}$ & $\mathrm{V}$ & $\mathrm{A}$ & $\mathrm{C}$ & $\mathrm{V}$ & $\mathrm{A}$ & $\mathrm{C}$ & $\mathrm{V}$ & $\mathrm{A}$ & $\mathrm{C}$ & $\mathrm{V}$ & $\mathrm{A}$ & $\mathrm{C}$ & $\mathrm{V}$ & $\mathrm{A}$ & $\mathrm{C}$ & $\mathrm{V}$ \\
\hline Accessions & & & & & & & & & & & & & & & & & & \\
\hline Charentais Vat $\mathrm{R}$ & & 3 & 1 & 3 & 2 & 1 & & & & 1 & 2 & & 2 & 2 & 1 & 1 & & 1 \\
\hline Chenggam & 2 & 5 & 1 & 3 & 3 & 1 & 4 & 4 & 1 & & & & 2 & 2 & 1 & 1 & 1 & 1 \\
\hline Durgapura Madhu & 2 & 3 & 1 & 3 & 3 & 1 & 4 & 4 & & 1 & 2 & 1 & 2 & 2 & & 1 & 1 & 1 \\
\hline Ginsen Makuwa & & 3 & 1 & 3 & 3 & 1 & 1 & 4 & & & & & & 2 & 1 & 1 & 1 & 1 \\
\hline K 5442 & & 3 & 1 & 3 & 3 & 1 & & & & & & & & & 1 & 1 & 1 & 1 \\
\hline Kanro Makuwa 1 & & & 1 & 2 & 3 & 1 & 3 & 4 & 1 & & & & & & 1 & 1 & 1 & 1 \\
\hline Kanro Makuwa 2 & & 3 & 1 & 2 & 4 & 1 & & & & & & & & & 1 & 1 & 1 & 1 \\
\hline Margot & 2 & 3 & 1 & 3 & 3 & 1 & 4 & 4 & 1 & 1 & 2 & 1 & 2 & 2 & 1 & 1 & 1 & 1 \\
\hline Meloncillo & & & 1 & 3 & 5 & 1 & & & & & & & & 2 & 1 & 1 & 1 & 1 \\
\hline Miel Blanc & & 4 & 1 & 4 & 5 & 1 & 6 & 4 & 1 & 1 & 2 & 1 & 2 & 2 & 1 & 1 & 1 & 1 \\
\hline PI 161375 & 2 & 3 & 1 & 3 & 3 & 1 & 4 & 4 & 1 & 1 & 2 & 1 & 2 & 2 & 1 & 1 & 1 & 1 \\
\hline PI 164323 & & & 1 & 5 & 6 & 1 & 6 & 6 & 1 & 3 & 4 & 1 & 4 & & 1 & 5 & 6 & 1 \\
\hline PI 266935 & 2 & 3 & 1 & 3 & 3 & 1 & 4 & 4 & 1 & 1 & 2 & 1 & 2 & 2 & & 1 & 1 & 1 \\
\hline PI 414723 & 2 & 3 & 1 & 3 & 3 & 1 & 4 & 4 & & 1 & 2 & 1 & 2 & 2 & 1 & 1 & 1 & 1 \\
\hline PI 482420 & & 3 & & 3 & 3 & 1 & & & & 1 & 2 & 1 & 2 & 2 & 1 & 1 & 1 & 1 \\
\hline Shiro Nashi Makuwa & & & & 3 & 4 & 1 & & & & & & & & 2 & & 1 & 1 & 1 \\
\hline Shiro Uri Okayama & & 4 & 1 & 3 & 3 & 1 & & & & & & & 2 & 2 & & 1 & 1 & 1 \\
\hline
\end{tabular}

\begin{tabular}{|c|c|c|c|c|c|c|c|c|c|c|c|c|c|c|c|c|c|c|}
\hline Smiths' Perfect & & & & 3 & 3 & 1 & 4 & 4 & 1 & 5 & 6 & & & & & 5 & 6 & 5 \\
\hline 90625 & 3 & 5 & 5 & 5 & 5 & 5 & 6 & 6 & 5 & 1 & 2 & 1 & 2 & 2 & 1 & 1 & 1 & 1 \\
\hline Anso AL77 & & 3 & 5 & 4 & 3 & 5 & 4 & 4 & 3 & 1 & 2 & 1 & 2 & 2 & 1 & 1 & 1 & 1 \\
\hline Fegouss 1 & & & 5 & 5 & 5 & 5 & & & & & & & & & 3 & 1 & 1 & 2 \\
\hline PI 164723 & 5 & & 5 & 5 & 5 & 5 & 6 & 6 & 5 & 1 & 1 & 1 & 2 & 2 & & 1 & 1 & 1 \\
\hline
\end{tabular}




\begin{tabular}{|c|c|c|c|c|c|c|c|c|c|c|c|c|c|c|c|c|c|c|}
\hline PI 224770 & & 5 & 5 & 4 & 5 & 5 & & & & 1 & 2 & 1 & & 2 & 1 & 1 & 1 & 1 \\
\hline Charentais T & & 5 & 5 & 3 & & 5 & & & & 5 & 6 & 5 & 4 & 6 & 5 & 5 & 6 & 5 \\
\hline Escrito 8429 & & & 5 & 4 & 5 & 5 & & & & 1 & 4 & 5 & 3 & & 5 & 1 & 1 & 5 \\
\hline MR-1 & & & & 5 & 5 & 5 & 6 & 6 & 5 & 5 & 6 & 5 & & & & 5 & 6 & 5 \\
\hline Persiski BR5 & 5 & 5 & 5 & 5 & 4 & 3 & 5 & 4 & & & & & 5 & 4 & 5 & 3 & 3 & 5 \\
\hline PI 234607 & & & & 4 & 5 & 5 & 6 & 6 & 5 & 5 & 2 & 5 & & & & 5 & 1 & 4 \\
\hline PI 282448 & & 3 & 5 & 3 & 3 & 5 & & & & & & & & 2 & 2 & 3 & 3 & 5 \\
\hline Védrantais & 5 & 5 & 5 & 5 & 5 & 5 & 6 & 6 & 5 & 5 & 6 & 5 & 5 & 6 & 5 & 5 & 6 & 5 \\
\hline PI 164320 & & 3 & 3 & 3 & 5 & 3 & 4 & 4 & 1 & 3 & 2 & 1 & & & 1 & 1 & 1 & 3 \\
\hline PI 255478 & & & 1 & 3 & 3 & 3 & & & & 1 & 2 & 1 & & 2 & 1 & 1 & 1 & 1 \\
\hline $\mathrm{n}$ & 10 & 21 & 28 & 33 & 32 & 33 & 19 & 20 & 15 & 21 & 21 & 17 & 19 & 23 & 25 & 33 & 32 & 33 \\
\hline
\end{tabular}

